The Journal of Engineering and Exact Sciences - jCEC, Vol. 06 N. 04 (2020)

journal homepage: https://periodicos.ufv.br/ojs/jcec

doi: 10.18540/jcecvl6iss4pp0540-0546

OPEN ACCESS - ISSN: 2527-1075

\title{
THE HOPE AS SOCIAL COMMITMENT IN THE PROCESSING OF TACROLIMUS
}

\author{
A. S. BERTAN ${ }^{1, *}$, M. A. CREMASCO ${ }^{1}$ \\ ${ }^{1}$ University of Campinas, School of Chemical Engineering, Campinas, São Paulo, Brazil
}

${ }^{*}$ Corresponding author. University of Campinas, School of Chemical Engineering, Campinas, São Paulo, Brazil, Phone: +55 46999144876

e-mail address: alessandra.suzin.bertan@gmail.com (A.S. BERTAN).

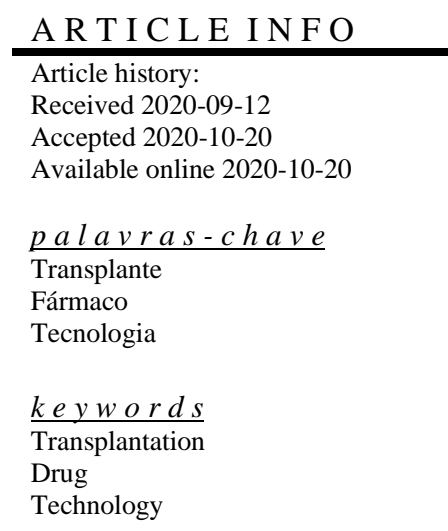

\begin{abstract}
A B S T R A C T
The 2020 year shows the fragility of the human been due to a virus that affects the people dependent of immunosuppressant agents. The aim of this paper it to contextualize the importance of the hope as essential element in chemical design to obtain tacrolimus, and to professionals involved in this research. It is presented the processing of this drug and the impact of their results on scientific and technological products, as well as in the human resource formation in the undergraduate and graduate levels, and impact in the society, showing that university extension can be done with external public, beyond of its technical production, bringing social hope to people who remain invisible to public policies.
\end{abstract}

R E S U M O

$O$ ano de 2020 mostra a fragilidade do ser humano devido a um vírus que atinge pessoas dependentes de medicamentos imunossupressores. $O$ objetivo deste artigo é o de contextualizar a importância da esperança enquanto elemento essencial no projeto químico para a obtenção de tacrolimo, bem como para os próprios profissionais envolvidos na pesquisa. É apresentado o seu processamento e o impacto de seus resultados em produtos científico e tecnológicos, assim como na formação de recursos humanos tanto em nível de graduação quanto de graduação, mostrando que a extensão universitária pode ser feita com o público externo, além de sua produção técnica, trazendo esperança social a pessoas que permanecem invisíveis às políticas públicas. 


\section{INTRODUCTION}

In Brazil, since the promulgation of 1988 Federal Constitution, the right to health is universal, including comprehensive therapeutic and pharmaceutical assistance. Brazil has the largest public transplantation system in the world, with the Unified Health System (SUS) responsible for financing $96 \%$ of all procedures related to the transplantation process (Oliveira et al., 2019). However, in view of the covid-19 pandemic, there is a totally new situation in people's lives, and profound impact for the current generation. The mankind has historic moment of extreme exceptionality, whose greatest recommendation is isolation, understanding that this isolation is not a personal choice, but a social necessity. Ordinary situations and demands could be assessed, circumvented, digested in such a way as to proceed with daily activities. It is not the case, because one lives in a universe that approaches science fiction, apocalyptic, but deeply real. Prudence and common sense are needed, with science and technology as determining allies, especially for the population considered at risk, such as those who need transplants and those who have already had the transplant. The pandemic, since it was enacted in March 2020 by the World Health Organization (WHO), has greatly affected the then 45,636 people on the waiting list for organ transplants in Brazil. In the case of kidney transplants, which representing $67 \%$ of the total number of surgical interventions, there were, in early March 2019, 510 transplant surgeries, whose number was reduced to 477 in the same period of 2020 (Melo, 2020). Among the reasons that caused such a decrease in surgeries, is the new treatment routine, since patients are extremely vulnerable to organ rejection, considering the suppressed immunity due to the use of medications, making people susceptible to infections by viruses, fungi and bacteria. In addition, the hospitalization itself can expose patients, such as what happened, at the end of May 2020, in the kidney transplant sector at the Hospital das Clínicas de São Paulo, where it stopped work at the end of April after the verification of that most patients were infected by the new coronavirus, whose central suspicion was that patients were being accidentally infected by health professionals (Preite; Sobrinho, 2020).

As can be seen, the coronavirus pandemic has altered and greatly changes the life of the population affected, for example, by chronic kidney disease, whose prospect of survival is a transplant. In addition to physical pain, the patient lives from the expectation of improvement or, in other words, from hope. When a kidney problem is detected, the patient has the hope of a quick cure, however he suffers when he finds out that his life will be governed by a treatment, such as dialysis. During dialysis, the patient has the hope for kidney transplant, participating in an endless wait for a compatible organ. Upon finding such an organ and performing the surgery of his graft, the patient has the hope that his organism will receive the new organ as his own and, for that, he starts administering immunosuppressant that, at the time of adapting the organism for the graft, exposes to the most diverse types of infection. The patient starts to have the double hope that the organism will adapt to the immunosuppressant, as well as to avoid exposures that could make him lose this organ. In addition, the patient has the hope of having the immunosuppressant at his disposal, so that he can start to sow the hope of living. But this cycle continues even after the end of the covid-19 pandemic, and the Universities and their researchers must be aware with this problematic.

In 2017, some media outlets reported the lack of tacrolimus in several Brazilians states, including São Paulo state, where $40 \%$ of transplant people live. In this same year, there was a court decision ending the productive development partnership that produced and supplied the drug to the Ministry of Health (Ferrari, 2018). The history of the lack of the drug persisted, as in 2019 news about the problem continued. According to an article published by Jornal Extra Classe in July 2019 , in the state of Rio Grande do Sul alone, approximately 6,000 transplant recipients still suffered from the uncertainty of the supply of the immunosuppressant. Likewise, it happened in the same year in Minas Gerais state, where Jornal Hoje em Dia reported that the wait for receiving the drug reached more than 6 months. This news clearly points to a productive issue to be resolved and that necessarily involves investment in research and development and innovation. In this aspect, the objective of this paper it to contextualize the importance of the hope as essential element in chemical design to obtain tacrolimus.

\section{RESULTS AND DISCUSSION}

\subsection{Chemical design}

A complete chemical design includes critical review of the idea, that there is a need for a process or product, selection of an appropriate process, process optimization, equipment design, description of the optimal operation, an economic forecast of its profitability. The design technical aspects usually involve standard engineering disciplines (Sherwood, 1972). A design for obtaining specific immunosuppressive drug from via fermentation, for example, requires knowledge of biology, chemistry, thermodynamics, mass transfer and unit operations, to culminate in a typical chemical engineering design, Figure 1.

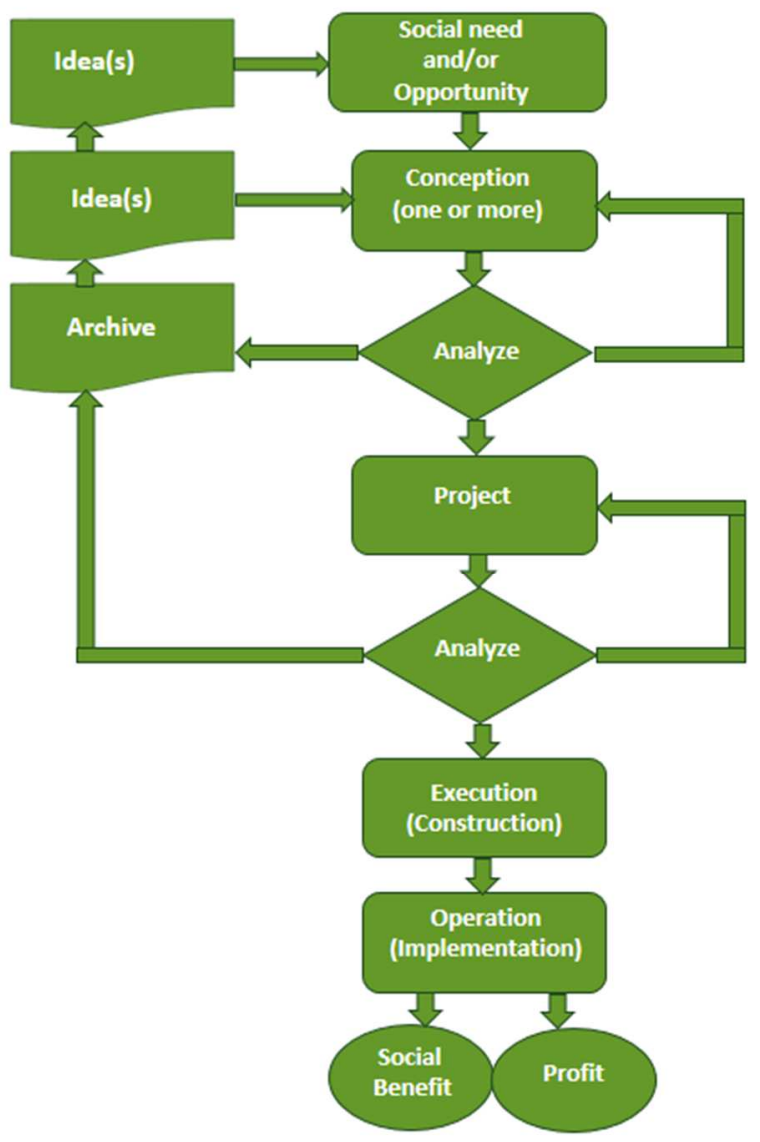

Figure 1 - Flowchart characteristic of a chemical design (adapted from Sherwood, 1972). 
The Journal of Engineering and Exact Sciences - jCEC, Vol. 06 N. 04 (2020)

journal homepage: https://periodicos.ufv.br/ojs/jcec

doi: 10.18540/jcecvl6iss4pp0540-0546

OPEN ACCESS - ISSN: 2527-1075

The design ideation begins when someone detects a social need and/or economic opportunity. In the case of immunosuppressant, the social needs are urgent. For the chemical industry, in its turn, this category of drug can become an economic opportunity. In this context, it is important to remember that Brazil ranks among the ten world powers in the chemical sector, standing behind China, United States, Japan, Germany and South Korea. On the other hand, Brazil presents a worrying record in its trade balance, with an explosive growth in the deficit from US\$ 1.5 billion in 1991 to over US\$ 32 billion in 2019.

According Vieira (2006), the added value of Brazilian exports is mainly concentrated in products of low technological intensity, such as cellulose, textiles, leather, and exports with a high degree of technology in the products account for less $10 \%$ of its total.

Among the products that involve high degree of technology, there are drugs. It can be seen, therefore, that when directing efforts, investments in research, development of immunosuppressant, including innovation in their processing, the result, in addition to bringing financial benefits to the industry, has an impact on the trade balance, reducing their deficit and, mainly, favors an important social demand.

\subsection{Tacrolimus processing}

According to the National Commission for the Incorporation of Technologies (CONITEC), tacrolimus is the most recommended drug for therapy of the treatment of kidney and liver transplantation, as well as for pancreatic transplantation therapy. This drug decreases the occurrence and severity of refractory rejection episodes and adverse events. In addition, tacrolimus is recommended for the treatment of autoimmune diseases, such as rheumatoid arthritis, lichen planus (Kovarik et al., 2003; Sanchez et al., 2004) as well as in bronchial asthma treatments (Pereira, 2006), dermatological disorders (Milikan, 2000; Dähnhardt, et al., 2019), such as vitiligo (Tamler et al., 2011), psoriasis, atopic dermatitis (Rodrigues et al., 2004; Chaudari et al., 2012), and eye diseases like uveitis (Hogan et al., 2007; Erdinest et al., 2019).

Products derived from tacrolimus produced by Astellas Pharma Inc. are the Prograf $\AA$, Advagraf $\AA$, Graceptor $\AA$, Astagraf XL®, Prograf XL® and Protopic $\AA$. In 2016, US\$ 1.841 billion of these drugs were marketed worldwide, representing $15.4 \%$ of the global immunosuppressive market (Ferrari, 2018).

Tacrolimus, known as FK-506 and fujimicin, Figure 2, is a macrolide lactone originally obtained from the fermentation of the Streptomyces tsukubaensis broth; this bacterium was found in the soil of Tsukuba, northern Japan (Moreira, 2008). Tacrolimus, molar mass of $804.018 \mathrm{~g} / \mathrm{mol}$ and empirical formula $\mathrm{C}_{44} \mathrm{H}_{69} \mathrm{NO}_{12}$, can be obtained via fermentation by several species of the genus Streptomyces in an aqueous nutrient medium, containing carbon and nitrogen sources, preferably under anaerobic conditions (Barreiro and Martínez-Castro, 2014).
The challenges related to the production of tacrolimus on an industrial scale are low process yields and complex purification, since other by-products are excreted by bacteria during secondary metabolism (Goranovič et al., 2012; Moreira, 2018).

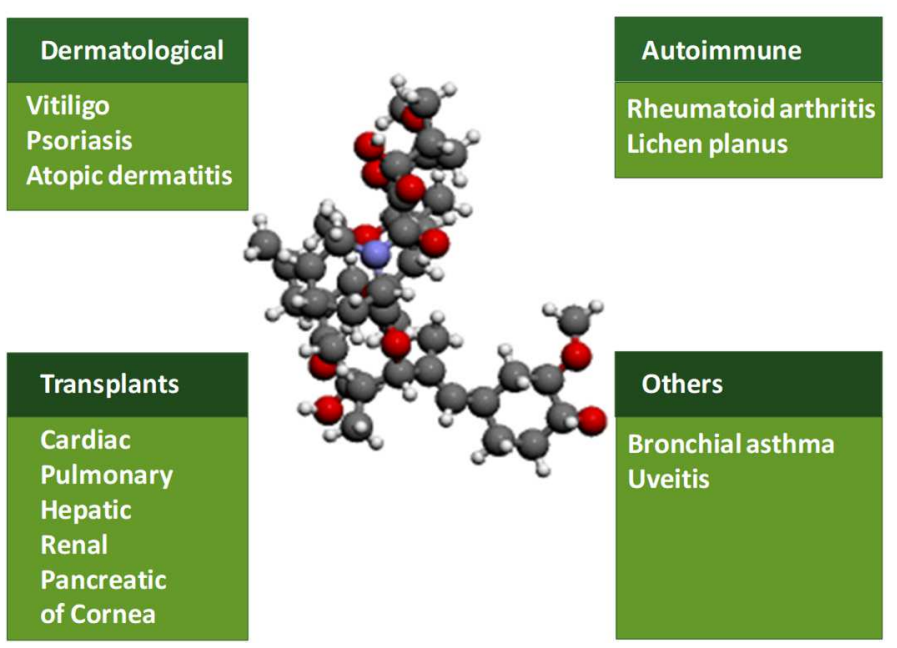

Figure 2 - Structural formula of tacrolimus and applications.

\subsection{Technical and social results}

In general, the production and purification of tacrolimus is summarized in Figure 3. Figures 4 and 5 show some steps along the processing. This tacrolimus processing was developed at Mass Transfer Process Laboratory (LPTM), School of Chemical Engineering (FEQ), University of Campinas (UNICAMP) (Cremasco and Ferrari, 2018), resulting in patent deposited at INPI (National Institute of Industrial Property). The results were discussed in the undergraduate and graduate classes, showing the importance of technical vision, economic opportunities necessarily linked to the social context, as shown in Figure 1. It should be noted that, in addition to the technical and scientific feasibility of processing tacrolimus, there was an important impact on society when the results of the research on its processing were released. The interview by the LPTM/FEQ/UNICAMP research group, published in the Jornal da Unicamp in early March 2020, had national repercussion and was broadcast in several sources, including TV Record's report, news on the websites of the Brazilian Chemical Society, Brazilian Society of Immunology, Brazilian Association of Intellectual Property, Transplant Center - RN, Government of the State of São Paulo, SP SAÚDE, SBT Interior, INVEST SP, News in FOCO MS, Innnovagro, among others. This repercussion demonstrates that the population needs to have hope, and that the academic community can nurture it with scientific, technical and social commitment.

Another social indicator in consequence of the media divulgation, was repercussion in social networks, as Facebook, the feeling of hope was common and the repercussions were even greater. Not only patients, but the general population leaves their opinion in the comments that show the importance of the drug. A transplanted patient with recent A.D.S wrote in 
the report published on TVB Record "My God, who will say after a few months with normal delivery, we are having a new medication problem and no expected return". Another follower of this same page, G.C, also left her feeling of hope "Thank God! That everything is right, to improve distribution." On the official page of the State University of Campinas on Facebook, where the news was released, followers highlighted the importance of research, L.M. wrote, "Congratulations to the Unicamp team, the family of transplant recipients are so grateful, and L.E. J said, "My son uses this medication. I know the importance of this study."

\section{Production}

(pre-inoculation, inoculation and fermentation)

\section{Removing insoluble}

(filtration, biomass centrifugation)
Lineage: Streptomyces tsukubaensis.

Culture medium: Corn starch, glucose, fructose, sucrose, maltose, corn oil, vegetable oils, amino acids, $\mathrm{CaCO}_{3}$, $\mathrm{KNO}_{3},\left(\mathrm{NH}_{4}\right)_{2} \mathrm{SO}_{4}$.

Fermenter specification

Standards: tacrolimus (macrolides).

Solvents: for analytical analysis: methanol, acetonitrile.

Filter and filter media; centrifuge.

Solvents: acetone, ethanol, acetonitrile, methanol, dextran blue

Stationary phase: C18, Diamonsil (for analytical analysis); Diaion HP-20, AMBERLITE@ XAD, polyvinyl benzene, activated carbon (for semiprepared column)

Equipment: Adsorption system, column packaging system, HPLC.

(chromatographic adsorption)

\section{Final preparation}

(crystallization)
99\% pure liquid tacrolimus

Techniques: evaporation, cooling, crystal filtration

Figure 3 - (Simplified) tacrolimus processing. 
The Journal of Engineering and Exact Sciences - jCEC, Vol. 06 N. 04 (2020)

journal homepage: https://periodicos.ufv.br/ojs/jcec

doi: 10.18540/jcecvl6iss4pp0540-0546

OPEN ACCESS - ISSN: 2527-1075

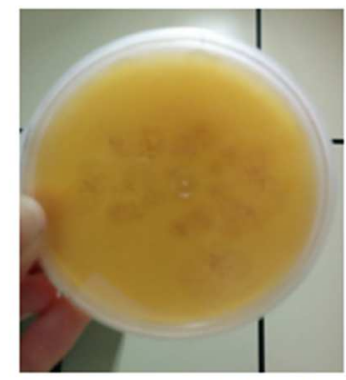

Streptomyces tsukubaensis cultivated in petri dish

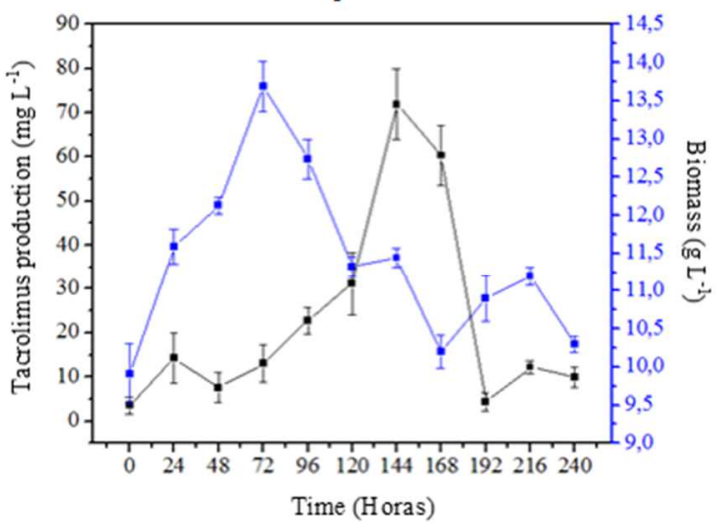

Photos: Jean Vinícius, Moreira, Wilson Murilo Ferrari, Séforah Carolina M. Silva, Alessandra S. Bertan

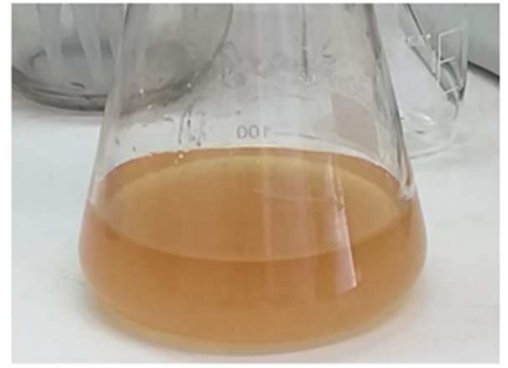

Pre-inoculum

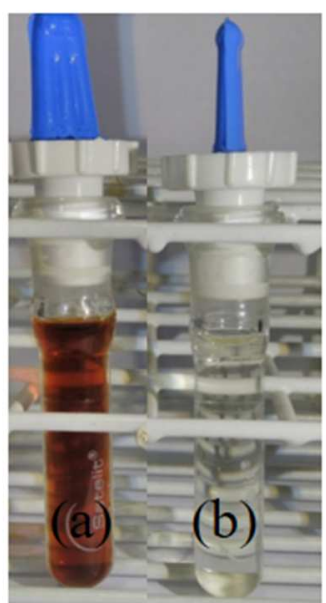

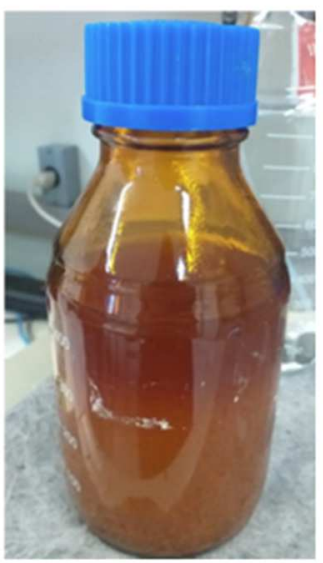

fermentative medium + acetone

Samples of the pre-purification of the fermented broth:

(a) concentrated broth

(b) pre-purified sample

Figure 4 - Production steps and primary tacrolimus separation.

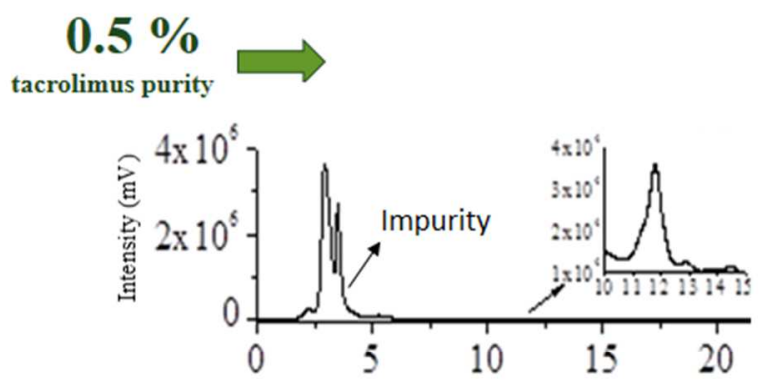

Solvent extraction (followed by evaporation and dilution)

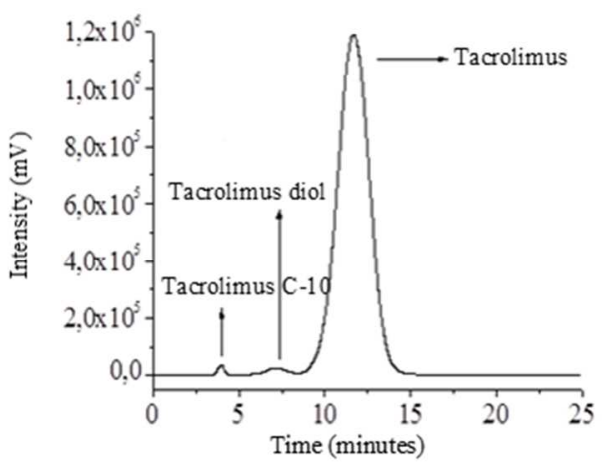

Adsorption followed by crystallization

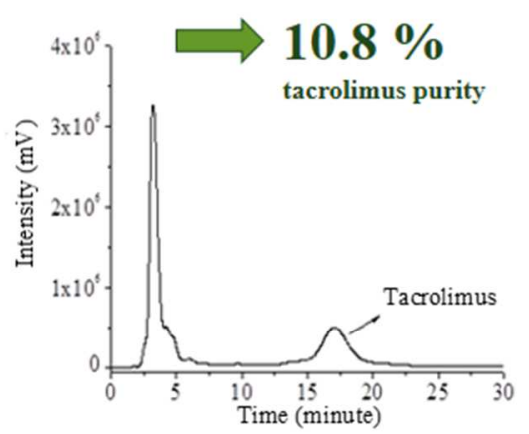

Adsorption

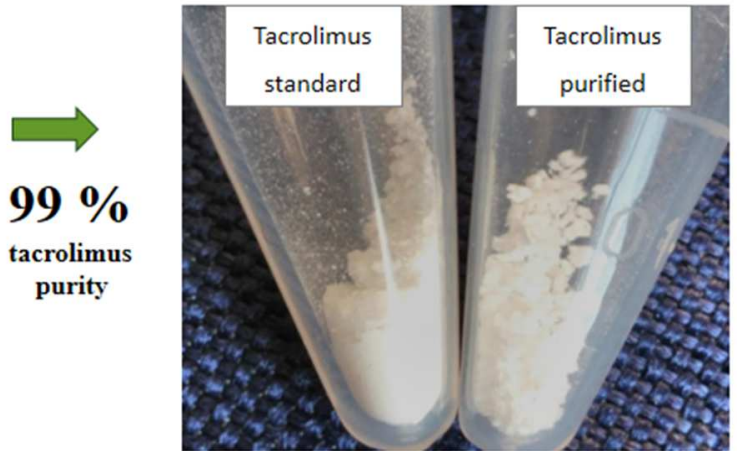

Ferrari, W. M. C. Processo de purificação de tacrolimo. Patent: Privilege of Innovation. Register number: BR10201801483, Registry Institution, M. A.; : INPI - National Institute of Industrial Property. Deposit: 20/07/2018

Figure 5 - Purification steps and final tacrolimus preparation. 
The social impact of this research increases the scientific and technical challenge for people involved with this subject. At present, for instance, there is a research about the use of microfiltration for the separation of biomass contained in fermented broth. In this case, it appears a new hope associated with the scale-up of tacrolimus production, and another hope happens, but now with the possibility of transference of this technology to an industry, and, here, another hope emerges: to offer the medicine for people, with low cost for government and ease access for patients. All this hope can be summarized by symbol of LPTM's research line, as presented in Figure 6.

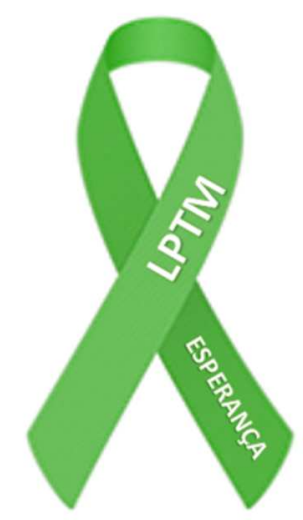

Figure 6 - LPTM laboratory symbol.

The green is the hope color, ant the green ribbon represents the donnation organ campaign. When associated with laboratory name (LPTM) and "esperança" (hope), this symbol demmonstred the social commitment of the researchers with people that have ordinary hope in their lives since to drink a little more water or a glass of wine (due to limitation of the liquid injection during dialysis treatment) to dream with end of their uncertainties. This symbol summarizes the empathy of science and technology with social commitment.

\section{CONCLUSION}

The year 2020 enters to history of mankind, exposing its fragility due to a virus, which affects from prime ministers to people that remain invisible to public policies, among these, those ones that maintain their lives through the use of immunosuppressant. Humanity's hope lies in science's quick response to beat the coronavirus, but the hope of those that need tacrolimus remain, because they depend on medicine at their disposal. Technology professionals, in particular from chemical engineering, have the differentiating role of proposing, developing chemical design to production of tacrolimus. Such professionals can be adding human value to their modus operandi. In other words, it is possible to do science and develop innovative technology with strong social commitment based on the hope. It is important to mention that hope is associated to believe in the realization of what one desires. It must always be greater than uncertainty. And the role of researchers is to minimize this uncertainty by applying their technical knowledge, in view of their social commitment and, mainly, exercising empathy during their studies, understanding the situation of patients waiting for a transplant and those that need tacrolimus for their survival.
Hope harbors the heart of every person who depends on medication, that is, is the meaning of life for them, as well as for researchers that found more meaning for their work. However, the patients can't live only with hope, but with science, technology and social commitment, the hope can to become itself in reality, and showing that life is a gifth for all.

\section{REFEREN CES}

\section{AGÊNCIA PAULISTA DE PROMOÇÃO DE INVESTIMENTOS E COMPETITIVIDADE} (INVESTSP). 2020. Available at : https://www.investe.sp.gov.br/noticia/unicampproduzfarmaco-essencial-para-transplantados-e-da-lista-dealto-custo-do-sus/>. Accessed on March 4, 2020.

\section{ASSOCIAÇÃO BRASILEIRA DA PROPRIEDADE} INTELECTUAL. Remédio para transplantados é produzido a baixo custo na Unicamp. 2020. Avaiable at $\cdot<$

https://abpi.org.br/wpcontent/uploads/2020/03/1583492 945.pdf >. Accessed on March 6, 2020.

BARREIRO, C.; MARTINEZ-CASTRO, M. Trends in the biosynthesis and production of the immunosuppressant tacrolimus (FK506). Applied Microbiology and Biotechnology, v. 98, p.497-507, 2014.

CENTRAL DE TRANSPLANTES DO RN. Unicamp produz fármaco essencial para transplantados e da lista de alto custo do SUS. 2020. Avaiable at:< https://www.facebook.com/CentralDeTransplantesDoRn />. Accessed on March 5, 2020.

CHAUDHARI, N. D.; TALANIKER, H. V.; GUPTA, S.; GUPPA, A.; DESMUKH, P.; RIZVI, A. Topical tacrolimus: A boom to dermatology. Journal of Pharmaceutical and Biomedical Sciences, v. 4, p.188192, 2012.

CREMASCO, M. A.; FERRARI, W. M. C. Processo de purificação de tacrolimo. Patente: Privilégio de Inovação. Número do registro: BR10201801483, Instituição de registro: INPI - Instituto Nacional da Propriedade Industrial. Deposit: 07/20/2018.

DÄHNHARDT, D.; BASTIAN, M.; DÄHNHARDTPFEIFFER, S.; BUCHNER, M.; FÖLSTER-HOLST, R. Comparative the effects of proactive treatment with tacrolimus ointment and mometasone furoate on the epidermal barrier structure and ceramide levels of patients with atopic dermatitis. Journal of Dermatological Treatment, p. 1-9, 2019.

ERDINEST, N.; BEN-ELI, H.; SOLOMON, A. Topical tacrolimus for allergic eye diseases. Current Opinion in Allergy and Clinical Immunology, v.16, p.535-543, 2019.

FERRARI, W. M. C. S. Recuperação e purificação de tacrolimo proveniente de Streptomyces tsukubaensis. 2018. 142 f. Tese (Doutorado em Engenharia Química) Universidade Estadual de Campinas, Campinas, SP, 2018.

GORANOVIC, D.; BLAZIC, M.; MAGDEVSKA, V.; HORVAT, J.; KUSCER, E.; POLAK, T.; SANTOSABERTURAS, J.; MARTINEZ-CASTRO, M.; 
The Journal of Engineering and Exact Sciences - jCEC, Vol. 06 N. 04 (2020)

journal homepage: https://periodicos.ufv.br/ojs/jcec

doi: 10.18540/jcecvl6iss4pp0540-0546

OPEN ACCESS - ISSN: 2527-1075

BARREIRO, C.; MRAK, P.; KOPITAR, G.; KOSEC, G.; FUJS, S.; MARTIN, J. F.; PETKOVIC, H. FK506 biosynthesis is regulated by two positive regulatory elements in Streptomyces tsukubaensis. BMC Microbiology, v. 12, p. 238, 2012.

GOVERNO DO ESTADO DE SÃO PAULO. Unicamp produz remédio essencial para transplantados e da lista de alto custo do SUS. 2020. Avaiable at:< https://www.saopaulo.sp.gov.br/ultimasnoticias/unicamp produzremedioessencialparatransplantados-e-da-listade-alto-custo-do-sus/>. Accessed on March 4, 2020.

HOGAN, A. C.; MCAVOY, C. E.; DICK, A. D.; LEE, R. W. Long-term efficacy and tolerance of tacrolimus for the treatment of uveitis. Ophthalmology, v.114, p.10001006, 2007.

INNOVAGRO. Unicamp, Brasil produce medicamentos esenciales para pacientes de trasplantes y la lista de altos costos del SUS. 2020. Available at: https://www.redinnovagro.in/noticia.php?idenNoticia=4 611>. Accessed on March 12, 2020.

JORNAL DA UNICAMP. Unicamp produz fármaco essencial para transplantados e da lista de alto custo do SUS. 2020. Available at: <https://www.unicamp.br/unicamp/ju/noticias/2020/03/0 3/unicamp-produz-farmaco-essencial-paratransplantados-e-da-lista-de-alto>. Accessed on March $12,2020$.

JORNAL EXTRA CLASSE. Medicamentos para transplantados continuam em falta no estado. 2019. Agência Brasil. Avaiable at : <https://www.extraclasse.org.br/saude/2019/07/medica mentos-para-transplantados-continuam-em-falta-nafarmacia-do-estado/>, Accessed on July 5, 2020.

JORNAL HOJE EM DIA. Falta de medicamentos prejudica transplantados em Minas, espera dura até seis meses. $2019 . \quad$ Available at: <https://www.hojeemdia.com.br/horizontes/cidades/falta -de-medicamentos-prejudicatransplantados-em-minasespera-dura-at\%C3\% A9-seis-meses-1.721728>, Accessed on June 18, 2019.

KOVARIK, B. K.; HOYER, P. F.; ETTENGER, R.; PUNCH, J.; SOERGEL, M. Cyclosporine absorption profiles in pediatric kidney and liver transplant patients. Pediatric Nephrology, v.18, p.1275 - 1279, 2003.

MELO, K. Pandemia de covid-19 diminui quantidade de transplantes no Brasil. Agência Brasil. 2020. Available at: <https://agenciabrasil.ebc.com.br/saude/noticia/202005/pandemia-de-covid-19-diminui-quantidade-detransplantes-no-brasil>, Accessed on May 11, 2020.

MILIKAN, L. E. Drug therapy in dermatology. $1^{\text {st }}$ ed., Boca Raton, CRC Press, 2000.

MOREIRA, J. V. Produção de tacrolimo via fermentação de Streptomyces tsukubaensis. 2018. 126 f. Tese (Doutorado em engenharia Química) - Universidade Estadual de Campinas, Campinas, SP, 2018.

MOREIRA, M. Estudo da ação do imunossupressor tacrolimus na pancreatite aguda experimental induzida pela arginina. 2008. 51 f. Dissertação (Mestrado em Clínica Cirúrgica). Universidade Federal do Paraná, Curitiba, PR, 2008.

NOTÍCIA EM FOCO MT. Remédio para transplantados é produzido a baixo custo na Unicamp. 2020. Available at: $<$ https://noticiaemfocomt.com.br/remedioparatransplantad os- 